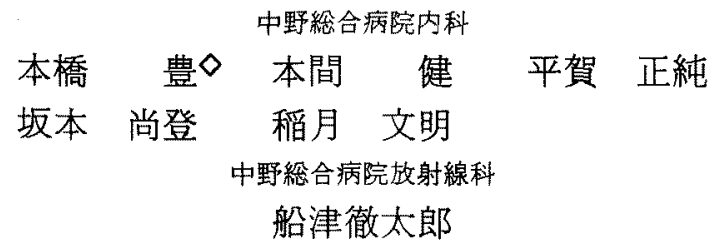

\title{
A CASE OF HUGE RETROPERITONEAL CHONDROSARCOMA
}

\author{
Yutaka Motohashi, MD, Takeshi Honma, MD, Masazumi HiRaGA, MD, \\ Hisato SaKamoto MD and Bunmei InazUKI, MD \\ Department of Medicine, Nakano General Hospital, Tokyo \\ Tetsutaro FunATSU, MD \\ Department of Radiology, Nakano General Hospital
}

\begin{abstract}
概要 後腹膜に発生する腫場の中で軟骨肉腫の報告はきわめて少ないが，われわれは報告例中 最大と思われる後腹膜軟骨肉腫の 1 例を経験したので報告する，症例は66才の男性で，上腹部 腫瘤を主訴として入院. 肝シンチにて肝右葉の大半を占める欠損像, 超音波検查にて数個の整

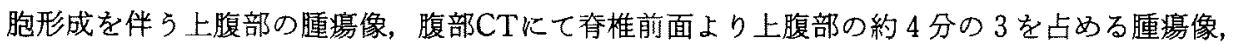

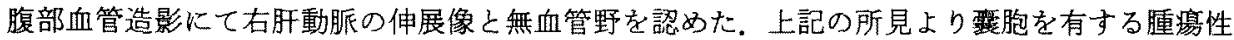
病变が疑われたが，この腫場が肝内のものか肝外のものかの診断は難しかつた，開腹手術によ る生検の結果, 後腹膜に発生した巨大な軟骨肉腫と判明した。腫瘍は肝臓, 胃, 右腎, 下大静 脈を王迫しており，摘除の結果 $33 \times 22 \times 10 \mathrm{~cm}$, 重量 $2600 \mathrm{~g}$ と判明した。これは報告例中最大のも のと思われる。一般に後腹膜腫場は巨大な腫瘤となることが多いにもかかわらず診断の確定が 難しい，近年進歩の著しい諸種の画像診断にて，部位診断は比較的容易になつたにもかかわら ず，必ずしも確定診断には至らないことが多い，腹部腫瘤の鑑別診断上，本症例のような後腹 膜腫焬をつ视に念頭に置くことが重要である。
\end{abstract}

はじめに

後腹膜に発生する腫瘍は腹部腫瘤として触知し らることが多く，手術治療により予後良好の症例 が多いので，早期の適切な診断が重要であるにも かかわらず，腹腔内腫瘍病変との鑑別が実際には 困難である，後腹膜腫演は病理学的にはリンパ肉 腫，脂肪肉腫，平滑筋肉腫などの報告があるが， 軟骨肉腫の報告はきわめて希である。われわれは 上腹部腫瘤を触知し, 諸種の画像診断にても腹腔 内の政胞性疾患との鑑別が困難で，開腹手術にて

[昭和57年 3 月 8 日受稿]

本症例は第316回日本内科学会関東地方会(昭和56年 12 月 12

日）で発表した。
巨大な軟骨肉腫と確定診断しえた症例を程験した ので報告する。

\section{症例}

患者：66才，男性，会社員。

主訴：上腹部腫瘤，食欲不振，体重減少。

家族歴：特記すべきことなし。

既往歴：45才，肺結核。

現病歴：昭和 42 年に右側腹部に腫瘤ができて 手術をしたが，このときは腐敗臭の強い膿を排膿 したという。その後著変なく経過していたが，昭 和55年 6 月垻より起床時覀心が强く，食欲不振毛 強くなつてきた９月になつて心窩部に硬い腫瘤 があるのに気付き，その後増大してくるのを感じ 
た。昭和 56 年 1 月当院外来受診し，肝シンチにて 肝右葉の占拠性病变を指摘され精査のため入院と なる。

入院時現症：身長 $169.5 \mathrm{~cm}$ ，体重 $60 \mathrm{~kg}$ ，血圧 $170 / 90 \mathrm{mmHg}$, 脈拍 $60 /$ 分整，負血・黄㾝は認めな い. 表在リンパ節は触知せず。頝部静脈の軽度怒 張を認める，胸郭は右側が陥凹し左右不対称。呼 吸音は右側で著明な低下，心雑音なし，肺肝境界 第 4 肋間. 腹部； 肝臓を心窩部にて約 $10 \mathrm{~cm}$ 触知 する，辺縁鈍，硬，表面平滑，可動性少，右側腹 部の肋骨切除部よりへルニア状に数個の腫瘤を一 塊として触知する，表面粗造，硬，可動性少で上 腹部腫瘤とつながつていると考えられた（図 1). 脾臓は触知せず，腹壁静脈の怒張著明。腹水なし。 下腿浮腫を両下肢に認める。神経学的に異常なし。

入院時検查成績：主要検查成績は表 1 亿示す とおりである．末梢血にて軽度の大球性正色素性

表 1。主要検査成績

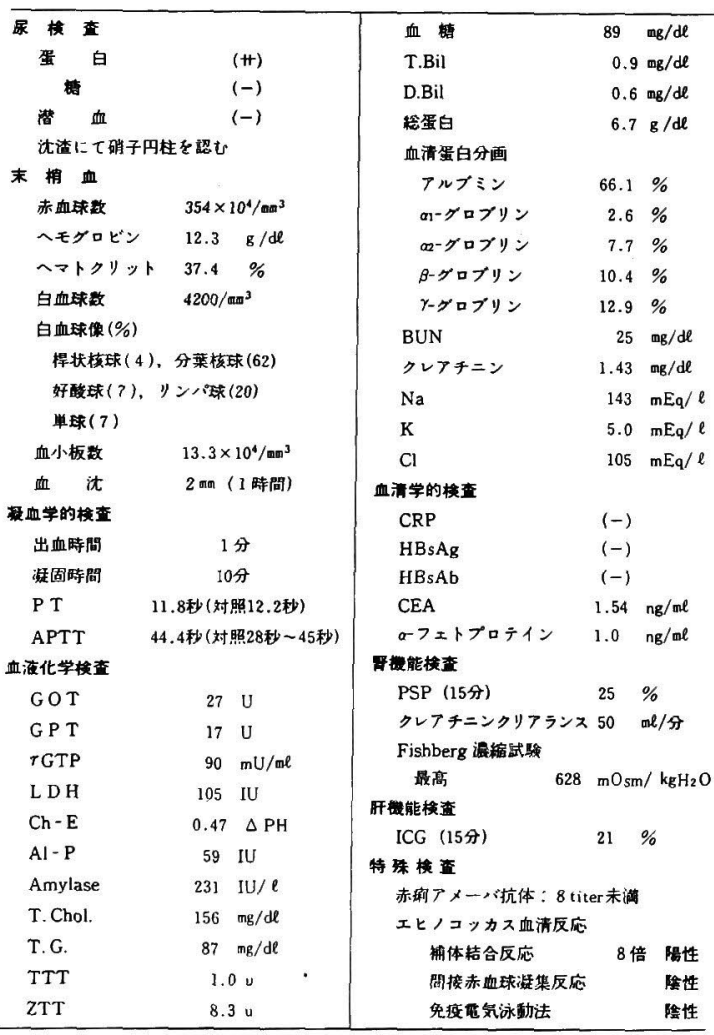

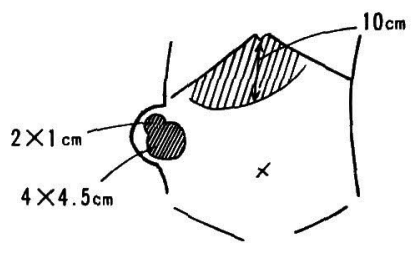

図1。腹部所見

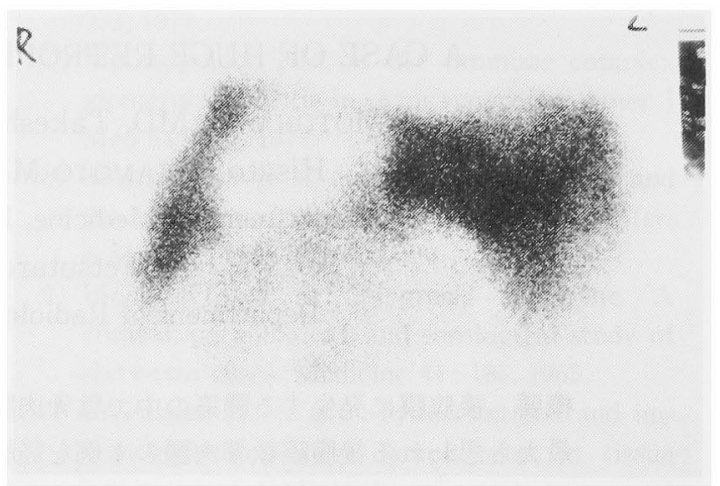

図 2. 肝シンチグラム，肝右葉にだるま状の巨大な陰 影欠損像がある。

貧血と相対的好酸球増加症を認めた。尿検査では， 蛋白尿と沈椬で硝子円柱を認めた，血液化学検査 では, $\gamma$-GTPの軽度上昇とCh-Eの低下を認める以 外に大きな異常は認めなかつた。腎機能検査では, クレアチニンクリアランスの低下とFishberg濃 縮試験で濃縮能の軽度低下を認めた。ICGは15分 値で $21 \%$ と延長を示した。胸部X線像では右肺野 全体が陳旧性の胸膜炎による之思われる胸膜肥厚 のため，濃厚な均等性陰影で抢执われていた。

臨床経過：入院時現症にて上腹部腫瘤を触 れ，肝シンチ（図 2 ）にて肝右葉全体を占める腫 瘍性病変が疑われたため，まず肝内腫湟を考えて 諸検査をすすめた，超音波検査（図 3）にて腹壁 下約 $2.5 \mathrm{~cm}$ より約 $10 \mathrm{~cm}$ にわたり複数の襄胞を伴 つた腫瘍状陰影を認めた。囊胞内の壁は不整で囊 胞内に点状エコーを認めた，腹部CT (図 4) にて は腹部正中に近い部分より右腹部側壁にいたり，

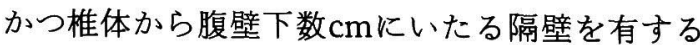
と思われる巨大な腫瘍陰影を認めた。腹部血管造 影celiac angiography（図 5 ) にては，腹腔動脈幹 


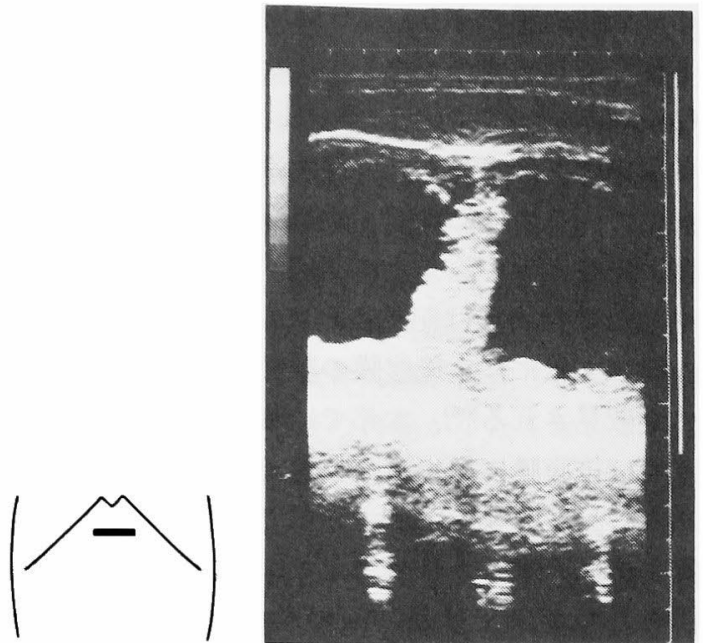

図 3．腹部ェコー．筫胞形成を伴う巨大な腫瘍陰影を示す。

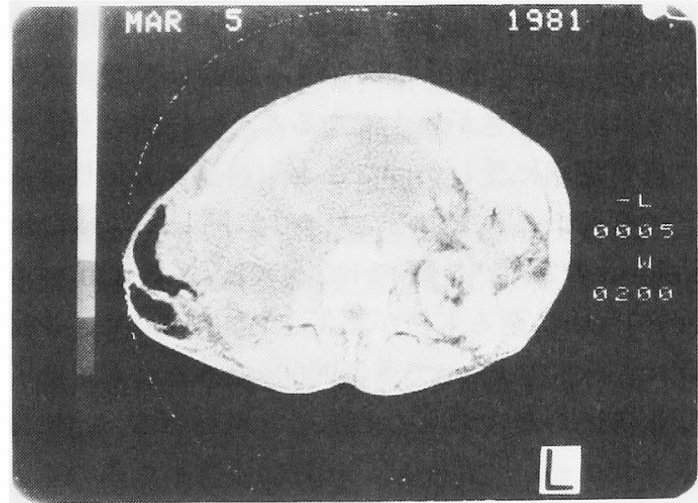

図 4. 腹部CT. 右上腹部の大半を占める巨大な腫瘍陰 影を示す。

の左方偏位と右肝動脈の伸展像が認められたが， 異常な腫瘍血管陰影は認められなかつた。上部消 化管造影検査では胃の大弯側が壁外性に圧排され 左方へ偏位している所見であり，経静脈性腎昷造 影では右腎の圧排によると思われる下方偏位の所 見であつた，以上のように，腫瘍が巨大であるに もかかわらず臨床症状に乏しく，検査所見にても 悪性腫瘍を思わせる所見に乏しいため，すず肝囊 胞症を疑つた，患者は第二次世界大戦中，北中国 にて情報将校として約 8 年間従軍したという生活 歴があり, 寄生虫性疾患の可能性も考光検査をす

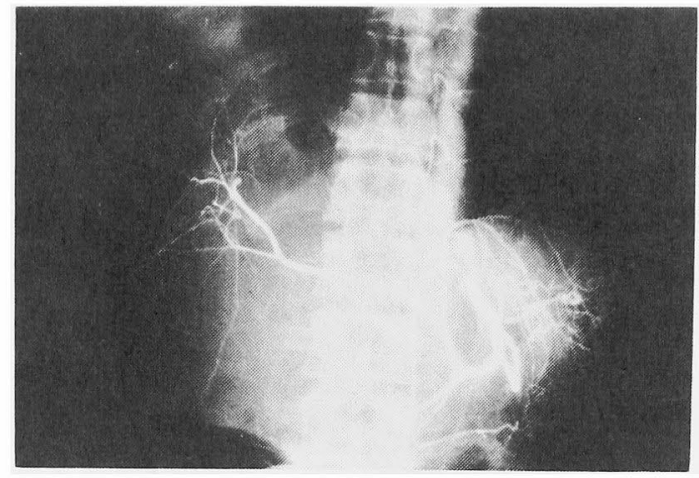

図 5.腹腔動脈造影。腹腔動脈幹の左方偏位之右肝動 脈の伸展像を示す。

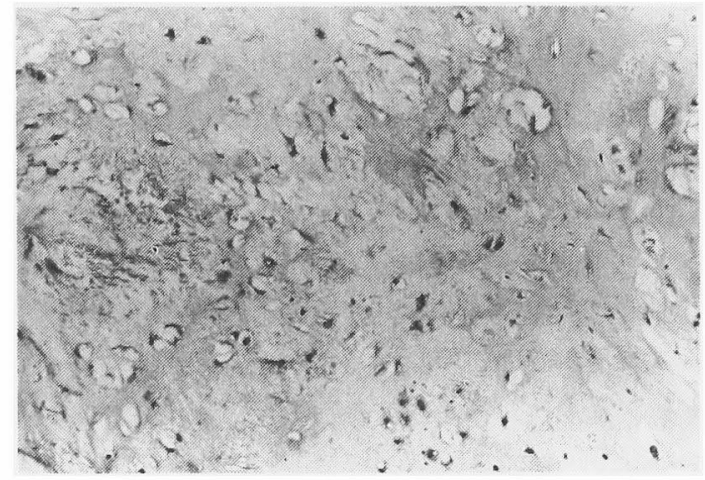

図 6。軟骨肉腫の組織像（HE染色，400倍）

すめたが，赤琍アメーバ抗体・エヒノュッカス血 清反応はいずれも陰性であつた。襄胞内穿刺を試 みたところ, 簧胞液は黄褐色の粘稠な液体で, 鏡 検にて寄生虫を認めず，細胞診にても異型細胞を 認めなかつた。上記のような経過にて確定診断が つかぬため，腫瘍摘除目的にて 6 月 9 日開腹手術 を施行した。開腹すると肝葴は薄くひき伸され萎 縮した状態で，その下に右上腹部全体を占める後 腹膜腫瘍の存在が判明した。同時に施行した生検 により軟骨肉腫と判明した（図 6)。この時点で摘 除術は施行されなかつた。根治手術は昭和 56 年11 月13日東京医科歯科大学第二外科にて施行され， $2600 \mathrm{~g}$ の囊胞を有する巨大な後腹膜腫瘍が摘除さ れ(図 7 ), 摘除標本の病理学的検査により軟骨肉 腫であることが確認された。手術直後に腎前性の 


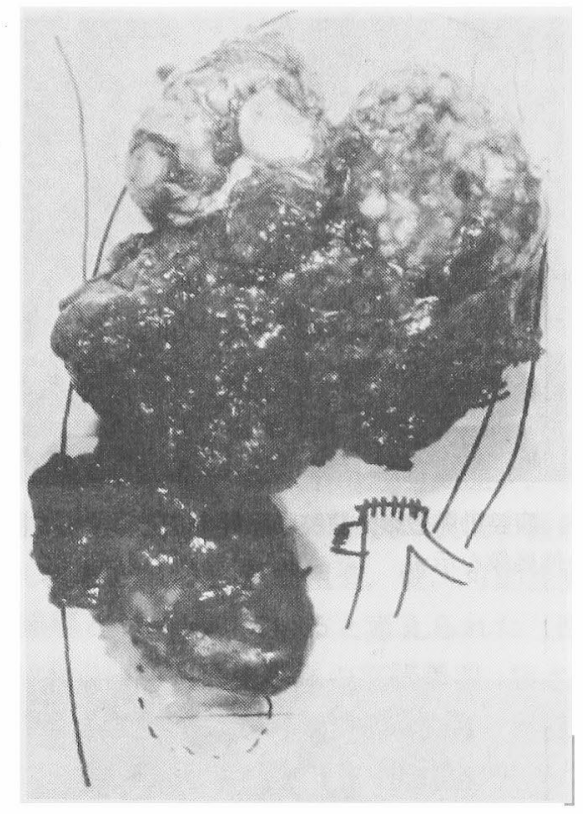

図 7 . 手術後の摘出標本. 畽場の大きさは $33 \times 22 \times 10$ $\mathrm{cm}$, 重量 $2,600 \mathrm{~g}$.

急性腎不全を合併したが, 保存的治療にて回復し， 以後経過は順調である.

\section{考案}

本症例の特徵は次の 2 点にまとめられる．第 1 に本症例は後腹膜に発生した $2600 \mathrm{~g}$ の大な軟骨 肉腫と判明したことである。この腫瘍が骨組織に 由来するものか, extraskeletalのものであるかは 不明である。手術所見では骨組織との関係を裏つ けるものはなく, extraskeletalの可能性が考えら れるが，本症例では14年前に詳細不明の胁骨切除 (右の第12肋骨)を受けており，肋軟骨が原発であ るといら可能性も完全に否定することはできな い. 第 2 に本症例では上腹部腫瘤が後腹膜腫瘍で あるか，腹腔内腫瘍であるかの鑑別が困難で，最 終的には開腹手術による組織学的検査で診断が確 定したことである，以下この 2 点にしほうつて考察 をすすめていくことにする，Ackermanの報告に よれば，後腹膜に発生する悪性腫瘍で最も多いの はリンパ肉腫で，ついで脂肪肉腫・平滑筋肉腫で あり, 軟骨肉腫の記載はない1), 一方成書の記載に よれば，軟部組織に発生する悪性腫瘍で最も多い
のは脂肪肉腫であり, extraskeletalの軟骨肉腫は $2 \%$ きわめて希である2. Stout ${ }^{31}$ の基準により, Goldenbergが1967年に集計したextraskeletalの 軟骨肉腫26例中最も多、発生部位は殿部・下肢の 18例で，その他には肩・手に 2 例ずつ，膀脱・胸 壁・上肢（手を除く）に 1 例ずつで，後腹膜に発 生した軟骨肉腫は記載されていない4).しかしそ の後の文献には, 後腹膜の軟骨肉腫を記載したも のが散見される5)6). 本邦では著者の検索しえた限 りでは後腹膜に発生した軟骨肉腫は 2 例の報告が あり，どちらも extraskeletalであるとしている。 第 1 例は 5 才 4 カ月の男児で, 右上腹部腫瘤を主 訴とした症例で重量 $500 \mathrm{~g}$ の軟骨肉腫が摘除され $た^{7)}$. 発生部位, 自覚症状, 好酸球增加症を認めた 点で本症例と類似点が多い，第 2 例は51才の男性 で，頻尿・排尿障害を主訴とし，小骨盤腔に発生 した軟骨肉腫の症例で重量 $436 \mathrm{~g}$ の腫瘍を摘除し ている ${ }^{8)}$. 本症例が上記 2 例と比較して特徽的な ことは，大きさが巨大であること，巨大になるま で自覚症状に乏しかつたこと, 再発の可能性が否 定できないことである.大きさに関してはextraskeletal の軟骨肉腫では $2.0 \times 1.7 \times 1.5 \mathrm{~cm}$ から $20 \times 15 \mathrm{~cm}$ に至るものが報告されているが4), 本症 例は $33 \times 22 \times 10 \mathrm{~cm}$ で重量 $2600 \mathrm{~g}$ であり，和そらく 報告例中の最大のものであると思われる，次に臨 床症状について言えば, 一般に後腹膜腫瘍の主要 症状は自覚的には腹痛, 腹部腫瘤, 体重減少であ り, 他覚的には腹部腫瘤, 腹部の圧痛, 腹部の突 出, 肝腫大であることが多い9 . 本症例もほぼこの ような主要症状を備えているが，2600g といら巨 大な大きさになるまで臨床症状に乏しかつたのは 再発が疑われるにもかかわらず，転移が認められ なからたためと思われる，Goldenbergの報告では 19 例中 5 例に転移を認めるが，本邦例では 3 例の いずれにも明らかな転移は認められず，今後症例 の蓄積によりこの点を明らかにする必要があると 思われる。一方，明らかな転移が認められないに もかかわらず，本症例では巨大な腫瘍が周囲の臓 器を広範に圧迫して扣り，肝右葉・十二指腸・横 行結腸・下大静脈のそれぞれの一部摘除之右腎の 
全摘出術を施行するといら大手術とないた。再発 に関してはGoldenbergの記載では19例中11例に 再発を認め, 再発は初回手術後 2 力月から15年に わたり，しかも4 例は 2 回以上の再発を扎しして いる4).本症例は14年前に詳細不明であるが，右側 腹部腫瘤の診断にて胁骨切除を伴ら開腹手術を受 けておりこの腫瘤が軟骨肉腫であり今回は前回 手術の未切除部より軟骨肉腫が再発した可能性は 否定できない．手術後の再発が少なくないことよ り術後の経過観察はとくに重要であると思われ る.

さて次に，本症例は肝ンンチ，超音波検查，腹 部CT, 腹部血管造影等の検査にもかかわらず確 定診断が困難であつたが，とくに最近進歩の著し い画像診断に重点を置いて考察をしていきたい．

本症例はまず肝シンチで肝内占拠性病变が疑わ れたが、これだけでは肝内性のものか肝外性のる のかの鑑別は難しかつた，䀒臓はもともと柔軟性 に富んだ蔵器であり, 周囲蔵器からの圧迫により false positive liver scanをつくりやすい. Freemanらの文献には後腹膜腫瘍の王迫による false positiveの症例も記載されて扣り，注意が必 要である10).

超音波検查では本症例のよ5に腫湟の存在，局 在診断，周用臓器との関係に関してはある程度明 らかにされるが，組織像すで推測しらる汪どの診 断的価值はなく，わずかに後腹膜血腫のみが診断 しうるとされている゙1. 本症例では扁平にひさ伸 され萎縮した肝蔵の直下に虽胞を伴つた腫瘍があ り，これが肝内のものか肝外のものかについての 診断はなかなか困難であつた。しかし図 3 から明 らかなように，本症例は隔壁を有する整胞かまた は中心壇死を伴う腫瘍である可能性が超音波検査 にて示唆され，鑑別診断の上で役立つた，本症例 の場合は幸い腸内ガス像によつてェコ一像が不鮮 明になることはなかつたが，一般の後腹膜腫瘍の 場合にはこのことが診断の妨げになると言われて いる ${ }^{12) 13)}$.

腹部CTでは本症例においては帮椎骨の前面よ り腹壁前面に近い部分まで占める巨大な腫瘍陰影
の存在が示され，腫福の局在および隔壁を有する 多房性構造も超音波検査より明確に示されてい る。一般に腹部CTでは超音波娭査のように腸内ガ スで画像が妨害されることもなく，腫湟の局在， 周囲蔵器との関係, 中心填死の有無等が超音波検 查より正確に描出され，診断的価値は高いとされ ている ${ }^{13)}$.しかし，超音波検査と同様に組織像亦で 推測しらるはどの質的診断には至らないとされて いる、以上のよらな非侵襲的検查は患者に負担を 与えることがなく，また経過観察に適しているた め有用性が高い。

上記のような諸検查に加えて，腹部血管造影は 後腹膜腫瘍の診断にな和有用であると再評価され ている、腹部血管造影は腫㾤の栄養動脈を明らか にし，腫瘍の局在を明確にするばかりでなく，そ の腫湟が何であるかについて重要な示唆を与えて くれることがある。本症例は当初肝内占拠性病変 の可能性が疑われたため, 腹腔動脈造影が施行さ れた. 所見としては腹腔動脈幹の左方偏位, 右肝 動脈の伸展像と肝シンチの占拠性病変部に一致し て avascular areaが認められた。胆管癌や転移性

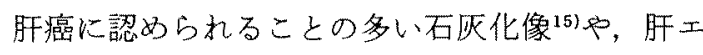
ヒノコッカス症に認められる capillary phaseの halo effect(裹胞周囲のradiodensityの増加 $)^{14)}$ \& 認められず，肝外性の腫瘍が疑われた，後腹膜腫 瘍はlumbar arteryが栄養動脈となることが多く, Damascellらはaortographyの重要性を強調して いる。同時に彼らは，後腹膜腫瘍でも軟骨肉腫は 脂肪肉腫や平滑肉腫のように単なるaortography だけでは所見が得られずささらにlumbar arteryへ の選択的な血管造影が必要であることを示してい る、本症例では確定診断後aortographyが施行さ れたが，王排所見のみだつた。

以上, 後腹膜腫癔の術前診断の困難さは従来の レントゲン診断に加え, 腹部エコー・腹部CTのよ らな最新の画像診断を用いても変ることはない。 媵腹膜腫煌は希な腫瘍であるが，腹部腫瘤として は巨大になることが多く，理学的に腫瘤として触 知し吝ても確定診断侄らず，つ称にどかしさ がある、診断の上で最も重要なことは，つ亦に鑑 
別診断上この疾患を念頭に置いていることで西る

といらことを最後に強調したい。 おわりに

後腹膜に発生した重量 $2600 \mathrm{~g}$ の巨大な軟骨肉腫 の 1 症例を報告し，臨床的特徵と鑑別㟝断の困難 性について考察を加えた。

謝辞 外科的治㞠につき御協力いただいた中野総合病院 副院長 仙石耕一先生, 東京医科歯科大学第二外科 上原 孝一郎先生, 久米進一郎先生, 平山廉三先生に感謝いたし ます。

\section{文献}

1) Ackerman LV: Tumor of the retroperitoneum mesentery and peritoneum. AFIP : 9, 1954.

2) Davis-Christopher: Textbook of Surgery, Saunders Co, Philadelphia, 1977, p615.

3) Stout AP and Verner EV: Chondrosarcoma of the extraskeletal tissue. Cancer $6: 581,1953$.

4) Goldenberg RR, et al: Chondrosarcoma of the extraskeletal tissues. J Bone and Joint Surg 49. A : 1487, 1967.

5) Damascelli $B$, et al : Angiography of retroperitoneal tumors. A review. Amer J Roentogenol
$124: 565,1975$.

6) Oyemade OA, et al: Retroperitoneal chondrosarcoma presenting with pleural effusion: A case report. J Natl Med Assoc 71 : 1181, 1979.

7）横山隆，他：後腹膜に発生した軟骨肉連の 1 例。 小児外科・内科 $8: 1338 ， 1976$ 。

8）酒谷邦康，橋本重夫：小骨盤腹膜外上り発生した 軟骨肉尰一1 摘出例。臨床病理 $27: 501 ， 1979$.

9) Duncan RE and Evans AT: Diagnosis of primary retroperitoneal tumors. J Urol $117: 19$, 1977.

10) Freeman $L M$, et al : False positive liver scans caused by disease processes in adjacent organs and structures. Brit J Radiol 42: 651, 1969.

11) Ponhold $W$ und Czembirek $H$ : Sonographische Differential-diagnose retroperitonealer Tumoren. Radiologie $20: 181,1980$.

12) de Santos LA, et al: Computed tomography in liposarcoma. Cancer $47: 46,1981$.

13) Stephans DH, et al : Diagnosis and evaluation of retroperitoneal tumors by computed tomography. Amer J Roentogenol 129: 395, 1977.

14) Rossi P and Ruzicka FF Jr: Differentiation of intrahepatic and extrahepatic masses by arteriography. Radiology 93 : 771, 1969. 